\title{
Kualitas Pelayanan Publik Pada Kantor Camat Dumai Kota
}

\author{
Muhaini Prihatin $^{1^{*}}$, Zaili Rusli ${ }^{2}$, Hasim As'ari ${ }^{3}$ \\ ${ }^{123}$ Magister Ilmu Administrasi Program Pascasarjana, Universitas Riau \\ Korespondensi : muhainiprihatin17@gmail.com
}

\begin{abstract}
Abstrak
Penelitian bertujuan untuk mengetahui kualitas pelayanan publik dan mengidentifikasi faktor penghambat pelayanan publik yang berkualitas pada Kantor Camat Dumai Kota. Metode penelitian deskriptif dengan pendekatan kualitatif. Teknik pengumpulan data melaluiobservasi, wawancara dan dokumentasi. Penentuan informan pemberi layanan dilakukan dengan teknik purposive sampling sedangkan untuk penerima layanan menggunakan teknik accidental sampling. Teknik analisis data dengan teknik analisis interaktif setelah dilakukan teknik trianggulasi data. Hasil penelitian menunjukkan bahwa pada dimensi tangible ditemukan sarana dan prasarana seperti bangunan atau ruangan kurang memadai, hal ini dapat dilihat dari ruangan yang cukup sempit untuk masyarakat yang banyak mengantri, jumlah kursi yang terbatas dan matinya AC dan TV membuat kondisi menjadi semakin tidak nyaman bagi masyarakat. Dimensi reliability masih ditemukan kekurangan pegawai yang belum mahir mengoperasikan perangkat pelayana. Dimensi responsivenessmenujukkan ketidakjelasan kepastian waktu pelayanan yang diberikan kepada masyarakat dalam pengurusan surat-menyurat hingga masyarakat tidak mengetahui kapan waktu penyelesaian menyebabkan masyarakat harus berulang kembali. Dimensi emphatydiketahui bahwa masih terdapat pegawai yang kurang ramah kepada masyarakat. Dimensi assurance masih belum adanya jaminan kompensasi kerugian waktu masyarakat yang merasa terbuang saat pengurusan yang lama. Faktor penghambat kualitas pelayanan publik yaitu sarana prasarana dan sumber daya.
\end{abstract}

Kata Kunci : Kualitas, Pelayanan, Publik, Kantor Camat

\begin{abstract}
This study aims to determine and identify inhibiting factors public services quality at the Dumai Kota district office. Descriptive research method with an qualitative approach. Data collection techniques through observation, interviews and documentation. Determining service provider informants by purposive sampling technique while for service recipients using accidental sampling technique. Data analysis techniques with interactive analysis techniques after data triangulation techniques. Results show that in the tangible dimension, facilities and infrastructure such as buildings or rooms are inadequate, making conditions uncomfortable for the community. The reliability dimension is still lacking in employees not yet proficient in operating services equipment. The responsiveness dimension shows the certainty of the service time provided to the community in managing correspondence so that the community does not know when the settlement time will cause the community to have to repeat it again. The dimension of empathy is known that there are employees who are still not friendly to the community. The assurance dimension is that there is still no guarantee of compensation for the loss of people's time that feels wasted during the long management. The inhibiting factors for the quality of public services are infrastructures and humans resource.
\end{abstract}

Key Words : Public, Services, Quality, District Office 


\section{PENDAHULUAN}

Pelayanan yang dilakukan secara langsung sudah dapat dinilai oleh masyarakat. Apabila pelayanan yang diberikan bersifat baik dan memuaskan, maka penilaian terhadap kinerja pelayanan adalah menjadi lebih baik (Hayat, 2017:174).Rendahnya kualitas pelayanan publik yang terjadi akhir-akhir ini merupakan salah satu sorotan yang diarahkan pada pemerintah dalam memberikan pelayanan kepada masyarakat. Namun hingga saat ini pelayanan yang telah diberikan kepada masyarakat, terkadang masih sulit untuk dapat diakses langsung oleh masyarakat dan prosedur yang terkadang berbelit-belit dan sering menyulitkan masyarakat ketika harus mengurus surat atau izin tertentu, biaya yang tidak jelas serta terjadinya pungutan liar (pungli), saat ini menjadi cerminan rendahnya kualitas pelayanan di Indonesia (Ambia, 2018:215).

Survey pendahuluan melalui observasi dan wawancara dengan aparatur yang dilaksanakan pada tanggal 16 November 2020 diperoleh informasi bahwa sistem pelayanan administrasi surat-menyurat di Kecamatan Dumai Kota sudah menggunakan komputerisasi, sedangkan untuk pencatatan antara lain seperti agenda surat masuk dan surat keluar, surat keterangan ahli waris, surat kuasa ahli waris, surat dispensasi menikah dan surat keterangan tidak mampu masih menggunakan buku manual dengan tulisan tangan aparatur yang melayani masyarakat pada saat itu.

Dari beberapa pelayanan sudah mencantumkan persyaratan pengurusan di dinding, namun tidak semua mengakomodir pelayanan yang ada. Kantor Kecamatan sudah menjelaskan alur pelayanan, namun belum mencantumkan berapa lama waktu penyelesaian pelayanan sehingga masyarakat tidak mendapatkan kepastian waktu. Alur pelayanan sudah mencantumkan waktu pelayanan namun hal demikian masih tergantung kesiapan aparatur pelayanan.

Tabel 1.1 Jumlah Pelayanan Publik Di Kantor Camat Dumai Kota Tahun 2020

\begin{tabular}{llc}
\hline No & \multicolumn{1}{c}{ Jenis Pelayanan } & Jumlah Pelayanan \\
\hline 1 & Surat Keterangan Ganti Rugi (SKGR) & 26 \\
\hline 2 & Kartu Keluarga (KK) & 383 \\
\hline 3 & Surat Pindah Domisili & 277 \\
\hline 4 & Surat Keterangan Tidak Mampu (SKTM) & 411 \\
\hline 5 & Surat Keterangan Ahli Waris & 130 \\
\hline 6 & Surat Kuasa Ahli Waris & 141 \\
\hline & Total & 1368 \\
\hline
\end{tabular}

Selanjutnya wawancaradengan masyarakat pada tanggal 17 November 2020 saat akan mengurus Surat Keterangan Tidak Mampu (SKTM) menyatakan bahwa mekanisme pengurusan masih harus menunggu aparatur pelayanan terkait walaupun ada aparatur lain di tempat. Masyarakat baru mengetahui persyaratan administrasi yang dibutuhkan sesuai dengan kebijakan pemerintah untuk melengkapi berkas pada saat datang ke kantor kecamatan, sehingga apabila terdapat kekurangan persyaratan mengakibatkan masyarakat harus bolak-balik minta surat pengantar dari Ketua Rukun Tetangga (RT) yang bersangkutan. Selanjutnya diperoleh informasi bahwa ada beberapa penandatanganan surat tidak dapat diwakilkan selain dari Camat, dengan padatnya jadwal dan kesibukan di lapangan maka waktu penyelesaian menjadi relatif lebih lama sehingga masyarakat menganggap aparatur kurang kompeten berimbas pada munculnya kesan yang kurang baik terhadap pemerintah.

Pelayanan publik menurut Mahmudi (2013:223) yaitu segala kegiatan pelayanan yang dilaksanakan oleh penyelenggara pelayanan publik sebagai upaya pemenuhan kebutuhan publik dan pelaksanaan 
ketentuan peraturan peraturan perundang-undangan. Aparatur pemerintah bertanggung jawab untuk memberikan pelayanan yang terbaik kepada masyarakat dalam rangka menciptakan kesejahteraan masyarakat. Masyarakat berhak untuk mendapatkan pelayanan yang terbaik dari pemerintah karena masyarakat telah memberikan dananya dalam bentuk pajak, retribusi dan berbagai pungutan lainnya.

Dwiyanto (2014:136) mendefinisikan pelayanan publik sebagai serangkaian aktivitas yang dilalukan oleh birokrasi publik untuk memenuhi kebutuhan warga pengguna. Pengguna yang dimaksudkan adalah warganegara yang membutuhkan pelayanan publik. Hal ini sesuai dengan pendapat Thoha (1991:41) dalam Anggara (2016:568) yang menjelaskan bahwa pelayanan publik merupakan suatu usaha yang dilakukan oleh seseorang/ sekelompok orang/ institusi tertentu untuk memberikan bantuan kemudahan kepada masyarakat dalam rangka mencapai tujuan tertentu. Birokrasi pemerintah merupakan institusi terdepan yang berhubungan dengan pemberian pelayanan masyarakat.

Untuk mengetahui kualitas pelayanan yang dirasakan secara nyata oleh konsumen, terdapat indikator ukuran kepuasan konsumen yang terletak pada 5 (lima) dimensi kualitas pelayanan menurut Zeithaml-Parasuraman-Berry dalam Hardiyansyah, (2018:63). Kelima dimensi tersebut mencakup beberapa sub dimensi sebagai berikut:

1. Tangibles (kualitas pelayanan yang berupa sarana fisik perkantoran, komputerisasi administrasi, ruang tunggu dan tempat informasi). Dimensi ini berkaitan dengan kemodernan peralatan yang digunakan, daya tarik fasilitas yang digunakan, kerapian aparatur serta kelengkapan peralatan penunjang.

2. Reliability (kemampuan dan keandalan untuk menyediakan pelayanan yang terpercaya). Dimensi berkaitan dengan janji menyelesaikan sesuatu sepertidiinginkan, penanganan keluhan konsumen, kinerja pelayanan yang tepat, menyediakan pelayanan sesuai waktu yang dijanjikan serta tuntutan pada kesalahan pencatatan.

3. Responsiveness (kesanggupan untuk membantu dan menyediakan pelayanan secara cepat dan tepat, serta tanggap terhadap keinginan konsumen). Dimensi responsiveness mencakup antara lain: pemberitahuan aparatur kepada konsumen tentang pelayanan yang diberikan, pemberian pelayanan dengan cepat, kesediaan aparatur memberi bantuan kepada konsumen serta aparatur tidak pernah merasa sibuk untuk melayani permintaan konsumen.

4. Assurance (kemampuan dan keramahan serta sopan santun pegawai dalam meyakinkan kepercayaan konsumen). Dimensi assurance berkaitan dengan perilaku aparatur yang tetap percaya diri pada konsumen, perasaan aman konsumen dan kemampuan (ilmu pengetahuan) aparatur untuk menjawab pertanyaan konsumen

5. Emphaty (sikap tegas tetapi penuh perhatian dari pegawai terhadap konsumen). Dimensi emphaty memuat antara lain: pemberian perhatian individual kepada konsumen, ketepatan waktu pelayanan bagi semua konsumen, peusahaan memiliki aparatur yang memberikan perhatian khusus pada konsumen, pelayanan yang melekat di hati konsumen dan aparatur yang memahami kebutuhan spesifik dari pelanggannya.

Penelitian bertujuan untuk mengetahui kualitas pelayanan publik dan mengidentifikasi faktor penghambat pelayanan publik yang berkualitas pada Kantor Camat Dumai Kota. Untuk memfasilitasi terhadap pengukuran suatu variabel atau secara operasional sebagai panduan penelitian maka pengembangan hipotesis menggunakan indikator dari dimensi kualitas pelayanan publik yaitu dimensi tangibles, dimensi reliability, dimensi responsiveness, dimensi assurance, dimensi emphaty dan faktor penghambat pelayanan publik yang berkualitas pada Kantor Camat Dumai Kota. 


\section{METODE}

Metode penelitian deskriptif dengan pendekatan kualitatif. Pendekatan kualitatif untuk penelitian berkaitan dengan penilaian subyektif dari sikap, pendapat dan perilaku (Kusumastuti \& Khoiron, 2019:3). Penelitian deskriptif ditujukan untuk mendeskripsikan suatu keadaan atau fenomena-fenomena apa adanya (Sudaryono, 2018:82). Penelitian dilaksanakan di Kecamatan Dumai Kota. Teknik pengumpulan data melalui observasi, wawancara dan dokumentasi. Objek penelitian yaitu informan pemberi layanan dilakukan dengan teknik purposive sampling sedangkan untuk informan penerima layanan menggunakan teknik accidental sampling. Prosedur purposive merupakan salah satu strategi menentukan informan yang paling umum di dalam penelitian kualitatif, yaitu menentukan kelompok peserta yang menjadi informan sesuai dengan kriteria terpilih yang relevan dengan masalah penelitian tertentu (Bungin, 2015:107). Informan penelitianyaitu 1) Camat, 2) Kepala Seksi Pemerintahan, staf dan pegawai honorer, 3) Kepala Seksi Kesejahteraan Sosial beserta staf dan pegawai honorer, 4) Masyarakat yang mengurus surat yang dibutuhkan. Instrumen yang digunakan yaitu pedoman wawancara.Teknik analisis data dengan teknik analisis interaktif setelah dilakukan teknik trianggulasi data.

\section{HASIL DAN PEMBAHASAN}

\subsection{Analisis Kualitas Pelayanan Publik Di Kantor Camat Dumai Kota 1. Dimensi Tangibles}

Tabel 3.1

Sarana Ruang Tunggu Pelayanan Pada Kantor Camat Dumai Kota

\begin{tabular}{clc}
\hline No & \multicolumn{1}{c}{ Fasilitas } & Jumlah \\
\hline 1 & Kursi tunggu & 4 \\
\hline 2 & AC (Air Conditioner) & 1 \\
\hline 3 & Komputer & 1 \\
\hline 4 & Printer & 1 \\
\hline 5 & Meja Pelayanan & 1 \\
\hline 6 & Televisi & 1 \\
\hline 7 & Ruang Ibu Menyusui & 1 \\
\hline
\end{tabular}

Terdapat pendingin ruangan dalam ruang tunggu pelayanan namun masyarakat masih terasa kepanasan apabila di dalam ruang tunggu penuh dengan mayarakat yang antri maka harus duduk menunggu di teras luar ruangan terbuka. Tempat duduk ruang tunggu dinilai masih kurang dilihat dari adanya beberapa masyarakat yang berdiri saat menunggu antrian.

Hasil wawancara informan diketahui bahwa masih terdapat kekurangan pada fasilitas yang ada pada Kantor Camat Dumai Kota, seperti toilet yang kurang dan akhirnya digunakan secara bersama dan bergantian antara pegawai kemudian televisi yang tidak menyala sebagai salah satu sarana hiburan bagi masyrakat yang lama mengantri dan terakhir $\mathrm{AC}$ atau pendingin ruangan yang tidak sejuk hal ini tentunya akan mengakibatkan masyarakat yang berada pada ruangan tunggu akan merasa panas dan tidak nyaman.

Kenyamanan tempat dalam proses pelayanan sangat penting bagi pengguna layanan. Selain itu tempat pelayanan juga sangat mempengaruhi kualitas pelayanan. Kecamatan sebagai penyedia layanan publik harus memberikan kenyamanan tempat bagi pengguna layanan yang datang, dari menyediakan tempat yang cukup agar pengguna layanan tidak merasakan sempit di dalam ruangan, kemudian menyediakan tempat duduk yang disesuaikan dengan ruangan yang ada. Selain tempat duduk, pendingin ruangan seperti AC juga dibutuhkan untuk kenyamanan pengguna layanan. Jika hari sudah mulai siang, 
maka biasanya di dalam ruangan akan menjadi lebih panas apalagi banyak orang yang mengantri untuk mendapatkan pelayanan.

\section{Dimensi Reliability}

Hasil wawancara informan masyarakat, layanan akan baik bergantung kepada pegawai yang melayani, jika pegawai yang tepat (memahami) maka layanan akan cepat selesai, jika pegawai tidak tepat (tidak memahami) maka layanan akan terjadi keterlambatan. Pegawai akan lebih mendahulukan layanan kepada masyarakat yang lebih mereka kenal. Masih menurut informan masyarakat menyatakan bahwa beberapa pegawai yang memberikan layanan kadangkala tidak begitu memahami standar pelayanan yang ada. Sebagai contoh ketika informan meminta kejelasan tentang suatu layanan, namun pegawai tersebut mengarahkan masyarakat ke bagian yang lain, yang juga meragukan apakah mereka mengerjakan layanan yang diminta oleh masyarakat.

Dari hasil wawancara tersebut diketahui bahwa sudah menjadi tuntutan bagi pegawai memberikan pelayanan yang baik dan maksimal kepada masyarakat yang datang untuk mengurus segala keperluan administrasinya, para pegawai seyogyanya dituntut untuk dapat melayani masyarakat dengan cepat dan tepat dengan pertimbangan jumlah masyarakat Kecamatan Dumai Kota yang sangat padat khususnya yang berkunjung ke Kantor Camat Dumai Kota untuk mendapatkan pelayanan. Selanjutnya diperoleh informasi bahwa masih terdapatnya pegawai yang belum begitu memiliki kemampuan dalam mengoperasikan perangkat komputer, hal demikian tentu saja merupakan menghambat pelayanan publik di Kantor Camat Dumai Kota. Kecakapan pegawai dalam penggunaan alat bantu saat melakukan proses pelayanan merupakan modal yang sangat krusial sebagai penunjang kualitas pelayanan publik. Namun, berdasarkan penelitian yang dilakukan, pegawai pelayanan yang ada di Kantor Camat Dumai Kota belum seluruhnya mampu dalam menggunakan alat bantu yang terdapat pada ruang pelayanan administrasi. Kemampuan para pegawai dalam menggunakan alat bantu dalam proses pelayanan sangat diutamakan agar proses pelayanan dapat berjalan dengan baik. Pegawai yang bertugas khsusus di bagian pelayanan administrasi masyarakat harus memiliki kemampuan untuk menggunakan alat bantu agar proses pelayanan berjalan dengan lancar.

\section{Dimensi Responsiveness}

Pada wawancara kepada informan masyarakat diperoleh informasi bahwa pegawai dalam memberikan layanan daya tanggapnya masih rendah, dinyatakan dengan pegawai terlalu bertele-tele saat menyampaikan informasi terkait pelayanan yang dibutuhkan. Seharusnya pegawai memiliki kemampuan untuk memastikan layanan dengan cepat dan tepat. Masyarakat hanya mengetahui bahwa para pegawai tentu saja sudah memiliki pengalaman yang banyak dalam melayani masyarakat yang tidak sedikit jumlahnya, karena pekerjaan ini telah berulang-ulang mereka lakukan. Bukannya malah semakin membuat masyarakat menjadi bingung saat menerima layanan.

Selanjutnya wawancara dengan informan pegawai Kantor Camat Dumai Kota yang menyatakan bahwa terdapat banyak pelayanan yaitu berupa pengurusan surat pengantar. Surat pengantar ini digunakan untuk pengurusan keperluan administrasi masyarakat wilayah Kecamatan Dumai Kota. Maka dari itu pegawai kemudian mengizinkan masyarakat untuk membawa surat pengantar tersebut untuk melakukan urusan pada instansi selanjutnya agar cepat selesai, karena apabila menunggu dari pihak kantor camat untuk melakukan pengurusan maka perlu waktu 2 (dua) atau 3 (tiga) hari.Pada saat penelitian terlihat bahwa masyarakat yang datang untuk mendapatkan pelayanan cukup banyak, hal ini tentunya membuat pegawai dituntut harus bekerja dengan maksimal dan cepat, namun sayangnya hal ini belum dirasakan oleh masyarakat yang datang mengurus Surat Keterangan Tidak Mampu (SKTM).

Secara keseluruhan dapat diketahui bahwa walaupun pihak Kantor Camat Dumai Kota dalam hal ini para pegawai sudah berupaya maksimal dan cepat memberikan pelayanan publik terhadap masyarakat 
namun pada kenyataannya bertolak belakang dengan apa yang dirasakan langsung oleh masyarakat. Berdasarkan hasil wawancara dengan masyarakat ditemukan bahwa masyarakat belum mendapatkan pelayanan yang maksimal dan cepat hal ini dirasakan sendiri oleh masyarakat yang merasa bahwa pelayanan yang diberikan belum cepat terutama dalam pengurusan SKTM dan lain sebagainya selain itu juga para pegawai yang dianggap kurang begitu ramah juga menjadi perhatian utama dalam hal ini, dan tentunya hal ini menjadi kendala dalam kualitas pelayanan publik di Kantor Camat Dumai Kota.

\section{Dimensi Empathy (Empati)}

Hasil penelitian berdasarkan wawancara informan masyarakat mengatakan bahwa layanan akan menjadi lebih cepat jika masyarakat sudah cukup mengenal pegawai Kantor Camat Dumai Kota dengan baik. Pegawai bahkan cenderung akan mendahulukan masyarakat yang kenal dengan mereka. Hal ini tentu saja membuat agak kecewa dan merasa dirugikan dengan perlakuan pegawai tersebut. Pegawai seharusnya tidak membeda-bedakan perlakuan kepada masyarakat yang sedang berurusan baik sudah kenal ataupun tidak. Sementara hasil wawancara informan kantor camat mengatakan bahwa perlakuan itu sebenarnya bukanlah untuk membedakan perlakuan pelayanan kami kepada masyarakat. Tetapi lebih kepada komunikasi yang sudah tercipta lebih baik, sehingga terlihat bahwa terjadinya perbedaan saat pemberian layanan.

Dari hasil wawancara tersebut diperoleh bahwa menurut pendapat dari masyarakat masih ada beberapa pegawai yang kurang ramah dalam memberikan pelayanan publik kepada masyarakat. Hal demikian tentu saja dapat mengakibatkan ketidaknyamanan bagi masyarakat yang datang ke Kantor Camat Dumai Kota, sudah tentu masyarakat harus mendapatkan pelayanan yang memuaskan karena sudah menjadi tugas dan tanggung jawab dari pegawai Kantor Camat Dumai Kota untuk memberikan pelayanan.

Sesuai dengan kebijakan yang berlaku yaitu dalam bentuk Peraturan Walikota Dumai Nomor 72 Tahun 2016 yang mengamanatkan aparatur penyelenggara di Kantor Camat Dumai Kota dalam rangka meningkatkan koordinasi penyelenggaraan pemerintahan dan pelayanan publik. Visi Kecamatan Dumai Kota juga menegaskan untuk menjadi yang terdepan dalam memberikan pelayanan yang prima. Selain itu juga tertuang dalam misi Kecamatan Dumai Kota untuk meningkatkan kualitas dan kinerja sumber daya aparatur yang profesional dan berkompetensi dengan berlandaskan imtaq dan iptek. Meningkatkan mutu dan kualitas pelayanan kepada masyarakat serta memberikan kemudahan data dan akses yang luas bagi masyarakat dalam memperoleh informasi dan pelayanan dengan tetap mengacu pada prosedur dan aturan yang berlaku (Profil Kecamatan Dumai Kota, 2020).

\section{Dimensi Assurance (Jaminan)}

Hasil penelitian berdasarkan wawancara informan masyarakat menyatakan bahwa pihak kantor camat sudah berusaha untuk memberikan jaminan layanan dengan baik. Ini ditandai bahwa pihak kantor camat selaku pemberi layanan memastikan tidak adanya biaya pelayanan yang dibebankan kepada masyarakat yang berurusan dan pihak kantor camat selalu berusaha untuk menyelesaikan layanan tepat waktu. Bahwa layanan akan selesai tepat waktu apabila Camat sedang berada di tempat/kantor, namun apabila Camat sedang ada kesibukan di luar maka masyarakat harus menunggu tanpa mendapat kepastian waktu selesai urusan surat-menyurat yang dibutuhkan masyarakat pada saat itu.

Senada dengan hasil wawancara dengan informan masyarakat lain yang mengatakan bahwa tidak adanya biaya layanan yang harus dikeluarkan oleh masyarakat, khususnya layanan surat pengantar. Dari hasil wawancara tersebut diperoleh bahwa masyarakat belum mendapatkan jaminan waktu tentang kesiapan pelayanan yang diberikan. Aturannya setiap bentuk pelayanan memerlukan adanya kepastian atas pelayanan yang diberikan. Bentuk kepastian dari suatu pelayanan sangat ditentukan oleh jaminan dari pegawai yang memberikan pelayanan, sehingga orang yang menerima pelayanan merasa puas dan yakin 
bahwa segala bentuk urusan pelayanan yang dilakukan atas tuntas dan selesai sesuai dengan kecepatan, ketepatan, kemudahan, kelancaran dan kualitas layanan yang diberikan.

Hasil wawancara di atas jelas menunjukkan bahwa saat penyelenggaraan pelayanan masih terdapat kendala teknis yang mempengaruhi kualitas pelayanan publik di Kantor Camat Dumai Kota, namun hal tersebut tidak memberikan jaminan pada masyarakat yang mendapat dampaknya yaitu harus menunggu dalam waktu lama, tidak adanya kompensasi waktu dan kepastian lainnya. Pemberian jaminan atas pelayanan yang diberikan oleh pegawai sangat ditentukan oleh performance atau kinerja pelayanan, sehingga pegawai tersebut dipercaya mampu memberikan pelayanan yang handal, mandiri dan profesional yang berpengaruh pada kepuasan pelayanan yang diterima masyarakat.

Jaminan dari suatu pelayanan dapat ditentukan dari adanya komitmen organisasi perangkat daerah yang kuat dalam menganjurkan pada setiap pegawai untuk memberikan pelayanan secara sepenuh hati dan intensif untuk memberikan kepuasan bagi masyarakat yang dilayani. Wujud lain dari jaminan yaitu adanya jaminan terhadap pegawai yang mempunyai kepribadian dalam berperilaku (personality behavior) yang cakap dalam memberikan pelayanan, yang tentu saja akan tampak berbeda dari pegawai yang memiliki watak atau karakter yang kurang cakap dalam memberikan pelayanan. Oleh sebab itu pihak Kantor Camat Dumai Kota sudah sepatutnya memberikan jaminan kepada warga yang merasa dirugikan dalam pengurusan surat-menyurat administrasi publik.

\subsection{Faktor Penghambat}

Hasil analisis faktor-faktor yang menjadi hambatan dalam kualitas pelayanan publik di Kantor Camat Dumai Kota adalah sebagai berikut:

\section{Sarana dan Prasarana}

Sarana dan prasarana merupakan bagian faktor penting yang sangat mempengaruhi dalam hal kualitas pelayanan publik, sebab kenyamanan akan dapat dinikmati apabila sarana dan prasarana lengkap dan mendukung proses pelayanan. Hasil observasi langsung mengenai sarana dan prasarana di Kantor Camat Dumai Kota dari segi infrastruktur organisasi pada dasarnya tidak begitu tampak kekurangan, kuantitas pegawai yang sudah cukup dan penempatan juga sudah sesuai dengan tugas pokok dan fungsinya masing-masing, struktur kedinasan juga telah memenuhi standar dan sesuai dengan aturan yang berlaku. Pada segi lainnya yaitu infrastruktur bangunan fisik terlihat kurang memadai yang ditandai seperti kondisi bangunannya yang memang sudah lama, tampak sempit bagi masyarakat maupun pegawainya. Keadaan ruangan yang cukup sempit bagi masyarakat dan juga ruangan yang begitu kecil bagi para pegawai dan terbatas menyebabkan banyaknya berkas yang berumpuk dalam satu ruangan, hal ini tentu saja merupakan penghambat dalam memberikan pelayanan publik yang berkualitas di Kantor Camat Dumai Kota.

Apabila sarana dan prasarana kurang memadai sudah pasti dapat mengakibatkan masyarakat yang memiliki keperluan untuk mendapatkan pelayanan menjadi tidak nyaman dan terusik yang akan berpengaruh terhadap penurunan kredibilitas suatu instansi. Adapun kondisi sarana dan prasarana dari Kantor Camat Dumai Kota dari poin kursi ruang tunggu yang seadanya saja hingga mengakibatkan masyarakat menjadi banyak mengantri dengan harus berdiri dan kepanasan. Lama waktu menunggu mengakibatkan masyarakat yang mengantri menjadi lelah berdiri, hal demikian tentu dirasakan sangat tidak nyaman. Selanjutnya beberapa sarana prasarana lain yang tidak berfungsi dengan baik seperti pendingin ruangan (AC) yang tidak dingin menyebabkan ruangan menjadi panas, begitu juga dengan televisi yang tidak menyala sebagai hiburan ditengah lamanya masyarakat yang mengantri baik sambil duduk maupun berdiri.

\section{Sumber Daya}


Sumber daya merupakan penentu dalam peningkatan pelayanan publik yang berkualitas, sumber daya bukan hanya saja mengenai sumber daya manusia (SDM) yakni pegawai yang berkerja pada satu instansi namun juga sumber daya yang selaku perangkat yang dipergunakan dalam beraktivitas dan berjalannya suatu kegiatan. Apabila sumberdaya pada suatu instansi terdapat permasalahan secara tidak langsung mampu memberi pengaruh aktivitas perangkat atau instrumen lainnya.

Sumber daya yang ditinjau pada Kantor Camat Dumai Kota dari sisi sumber daya manusia masih ditemukan kekurangan antara lain masih adanya pegawai yang belum begitu menguasai dalam pengoperasian perangkat komputer dan juga beberapa instrumen penunjang utama dalam bekerja juga perlu menjadi perhatian. Sebagai contoh masih dijumpai terjadinya kesalahan perangkat (error) dan rusak ringan maupun berat yang pasti dapat berpengaruh dalam menghambat kinerja pegawai. Keadaan ini dapat saling terkait dan pada waktu yang bersamaan akan mempengaruhi kecepatan atau keterlambatan penyelesaian satu pekerjaan

\section{KESIMPULAN}

Berdasarkan hasil uraian dan analisis penulis tentang kualitas pelayanan publik pada Kantor Camat Dumai Kota, maka penulis menarik kesimpulan sebagai berikut:

1. Sarana dan prasarana seperti bangunan atau ruangan yang terdapat pada Kantor Camat Dumai Kota kurang memadai, hal ini dapat dilihat dari ruangan yang cukup sempit untuk masyarakat yang banyak mengantri, jumlah kursi yang terbatas dan matinya AC dan TV membuat kondisi menjadi semakin tidak nyaman bagi masyarakat.

2. Beberapa pegawai telah memahami pekerjaan dan tugasnya masing-masing dengan baik, namun masih ditemukan kekurangan yaitu masih belum mahir mengoperasikan perangkat pelayanan dan bahkan kurang ramah kepada masyarakat.

3. Ketidakjelasan kepastian waktu pelayanan yang diberikan kepada masyarakat dalam pengurusan surat-menyurat hingga masyarakat tidak mengetahui kapan waktu penyelesaian urusan mereka menyebabkan masyarakat harus berulang kembali ke kantor Camat Dumai Kota dan terakhir belum terdapat jaminan kompensasi kerugian waktu masyarakat yang merasa terbuang saat pengurusan yang lama sampai 2-3 hari.

\section{SARAN}

1. Pihak Kantor Camat Dumai Kota harus merenovasi gedung dengan memperbesar ukuran ruangan atau memindahkan pelayanan administasi ke ruangan yang lebih besar yang terdapat di ruangan lain dengan memperhatikan keadaan masyarakat yang cukup banyak datang setiap harinya, segera memperbaiki pendingin ruangan, televisi serta menambah jumlah tempat duduk demi kenyamanan kedua pihak.

2. Bagi pegawai pelayanan yang belum cakap agar dapat mengadakan pelatihan atau kursus pengoperasiaan perangkat komputer yang up to date dan mengutamakan etika untuk lebih ramah kepada masyarakat.

3. Membuat Standar Operasional Prosedur (SOP) pelayanan administrasi publik demi memberikan kepastian kepada masyarakat mengenai waktu penyelesaian urusan keperluan serta mengedepankan hak-hak masyarakat dalam memperoleh pelayan yang berkualitas. 


\section{DAFTAR PUSTAKA}

[1].Ambia, N. 2018. Pengaruh Efektivitas Kerja Pegawai Terhadap Kualitas Pelayanan Publik Di Kelurahan Sidorame Barat I Kecamatan Medan Perjuangan. Jurnal Publik Reform UNDHAR MEDAN, 3(1), 214-262.

[2].Anggara, S. 2016. Ilmu Administrasi Negara (B. A. Saebani (ed.)). Pustaka Setia.

[3].Bungin, M. B. 2015. Penelitian Kualititatif (Kedua). Prenada Media Grup.

[4].Dwiyanto, A. (Ed.). 2014. Mewujudkan Good Governance Melalui Pelayanan Publik. Gajah Mada University Press.

[5]. Hardiyansyah. 2018. Kualitas Pelayanan Publik. Gava Media.

[6].Hayat. 2017. Manajemen Pelayanan Publik. Rajawali Pers.

[7].Kusumastuti, A., \& Khoiron, A. M. (2019). Metode Penelitian Kualitatif. Lembaga Pendidikan Soekarno Pressindo.

[8].Mahmudi. 2013. Manajemen Kinerja Sektor Publik. Sekolah Tinggi Ilmu Manajemen YKPN.

[9]. Sudaryono. 2018. Metodologi Penelitian. Rajawali Pers.

[10].Peraturan Walikota Dumai Nomor 72 Tahun 2016 tentang Kedudukan, Susunan Organisasi, Tugas Dan Fungsi Serta Tata Kerja Kecamatan Dan Kelurahan.

[11].Profil Kecamatan Dumai Kota Tahun 2020. 